\title{
Insecticides Rotation Strategy for Controlling Bemisia Tabaci (Genn.) on Tomato Crop
}

\author{
Farida A.Ayad ${ }^{1}$,H.S. Taha ${ }^{1}$, A. F.E. Afsah ${ }^{2}$, A.R.I. Hanafy ${ }^{2}$, S.A.G. Metwally ${ }^{2}$ and Sherif Ayoub $^{3}$
}

\begin{abstract}
Insecticides rotation strategy was applied after treatment of the seedlings of tomato variety Rover (E-446) F1 hybrid in the nursery using thiamethoxam and imidacloprid (foliar and drench application) for the control of Bemisia Tabaci. Twelve treatments with biorational and conventional insecticides in a rotation programs was applied at Syngenta Kaha Station, Kalubia Governorate, Egypt.
\end{abstract}

The best treatment was seedlings treated with thiamethoxam at $30 \mathrm{~g} / 20000$ seedlings as drench application in the nursery and a sequence of thiamethoxam, twice fenpropathrin, and twice pymetrozine in open field. It gave good results for controlling the adults stage of $B$. tabaci and minimized the number of infected plants and percent surface area showing virus symptoms. Also, the highest yield of tomato was obtained after five sprays during the season.

The present study suggests that drench application in the nursery was a good treatment in reducing and delaying attacks by $B$. tabaci.

\section{INTRODUCTION}

The whitefly, Bemisia tabaci Gennadius causes great concern among agricultural producers throughout the world. This pest damages plants in several ways including direct damage from feeding individuals, production of massive quantities of honey dew upon which sooty mold fungus can grow which interferes with the photosynthesis process, thus delaying crop development and decreasing the yield; and transmission of germiniviruses (Costa et al.,1991; Brown.,1992; Costa et al.,1993). The combination of these effects has promoted this species to be one of the most damaging pest in agriculture production of vegetable crops specially tomato. Additionally this pest is notable for its ability to develop resistance to chemical pesticides quickly (Costa \& Brown., 1991; Cahill et al., 1995, 1996).

Depending upon the circumstances, certain insecticides use strategies may be more effective than others in delaying the onset of insecticide resistance in a particular pest and geographical area. Among the more common strategies that have been characterized include the use of insecticides sequentially, in mixture or rotation (Georghiou., 1983; Curtis.,1985; Tabashnik., 1989). Geoghiou (1994) further defined resistance management tactics according to the intensity of insecticide exposure and the sequence or diversity of insecticides that are applied. The particular strategy employed ideally should account for the risks of resistance developing to the candidate insecticides based on knowledge of the biology and ecology of the pest species (Keiding,1986; Georghiou,1994). Efforts to measure resistance changes in fields experimentally subjected to various insecticide regimens have been notably few

Immaraju et al., (1990) found that resistance levels increased most under the sequential regimen and that rotation of insecticides was superior to mixtures. Mc Kenzie \& Byford (1993) reported that the highest resistance level developed in the single insecticide, sequential use schemes, whereas treatments with mixtures or rotations of insecticides yielded much lower resistance.Resistance to various insecticides belonging to different classes has been well documented in $B$. tabaci around the world (Dittrich et al., 1985, 1990; Prabhaker et al., 1985, 1992; Horowitz et al., 1988; Cahill et al., 1995) and has been implicated as a factor in its elevated pest status (Dittrich et al., 1985).

Our objective was to apply rotation strategy through a crop season by measuring the toxic responses of B. tabaci. We were also interested in exploring the control efficacies of different insecticide used strategies by measuring whitefly densities and tomato yields in field plots subjected to different insecticide use regimens to evaluate the pest management potential of this strategy. Finally this work was done in order to find some better control measures for such injurious pest.

\section{MATERIAL AND METHODS}

A field trial was conducted at Syngenta Agricultural Research station at Kaha, Kalubia Governorate, Egypt. Seedlings of tomato variety E- 448 $\mathrm{F}_{1}$ hybrid were planted in trays on Sep. 22. Twenty four

\footnotetext{
${ }^{1}$ Central Agricultural. Pesticides Laboratory Agric. Res. Center, Giza Egypt.

${ }^{2}$ Plant Protection Research Institute. Agric. Res. Center. Giza, Egypt.

${ }^{3}$ Syngenta Kaha Station, Kalubia Governorate, Egypt.

Project \# FC/20/28-97, financed from Bureau de Liaison AgricoJe.,

Franco-Egyptien.

Received June20, 2009, Accepted June29, 2009
} 
hours before transplanting, seedlings were divided into five parts and nursery treated as follows:

- Thiamethoxam at $30 \mathrm{~g} / 20000$ seedlings as foliar application [plots $101 \& 102$ ]

- Thiamethoxam at $30 \mathrm{~g} / 20000$ seedlings as drench application [plots $103 \& 104$ ]

- Imidachloprid at $125 \mathrm{ml} / 1001$ as foliar application [plots $105 \& 106$ ]

- Imidachloprid at 200g/20000 seedlings as drench application [plots $107 \& 108$ ]

- untreated check [plots 109,110,111,112]

Seedlings of tomato, 34 days old, were transplanted in open field plots on October 26 after wheat crop. The experimental design was established on area of one feddan included twelve treatments in addition to untreated check, 4 replicates were used. Treatments were taking numbers from 101 to 112 according to nursery treatments. Normal agricultural practices were followed by the application of the recommended rates of the biorational and conventional insecticides in a rotational program as indicated in Table1.

Applications were carried out using a single nozzle Knapsack sprayer and a spray volume of 2001/feddan. Sprays were done according to the economic threshold (less than one/ compound leaf).

The efficacy of the insecticides against the adult stage was determined by counting insects on the lower surface of 25 compound leaves at random. Counts were made in the early morning when flight activity is minimal according to Butler et al (1988). Pre-treatment counts were done in the early morning just before application and at $1,3,6,9,12,15,18,21,24,27,30$, $33,36,39,42,45$ days after transplanting (DAT)

The efficacy against eggs, nymphs and immature stage (eggs + nymphs) was evaluated by inspection of 20 compound leaves at random every $34,42,49,55$, and 62 DAT Leaves were transfered to the laboratory and stages were counted with the aid of a binocular microscope.Percent reduction of all stages (adults, eggs, nymphs and all immature) of B. tabaci was calculated for all treatments using the equation of Henderson \& Tilton (1955).

The virus symptoms were evaluated on 25 randomized plants in each replicate 18,26,36,45,54,64 and 73,83 and 93 (DAT).Symptoms were evaluated morphologically. The number of plants exhibiting virus symptoms was recorded and percent of surface area showing virus symptoms was estimated visually.

\section{RESULTS AND DISCUSSION}

Data in Table 2 showed the efficacy of the chemicals used on adults of B. tabaci and represented as percent reduction of infestation at different time intervals from treatment. The treatments could be arranged in a descending order as follows:

$104>102>103>101>106>108>110>111>109>105>$ 107.

The best result was given by treatment 104 in which tomato seedlings were treated at nursery with thiamethoxam as drench application, at open field with thiamethoxam as foliar application followed by twice applications of fenpropathrin and twice applications of pymetrozine. (5 field applications).

Table 3 represented the efficacy of the chemical used against eggs, nymphs and immature stage which the efficacy of the treatments on egg stage could be arranged in a descending order as follows.

$103>106=108>105>104>107>110>101>111>$ $109>102$.

The best result was given by treatment 103 in which tomato seedlings were treated at nursery with thiamethoxam as drench application and at open field with twice applications of fenpropathrin followed by twice applications of Pymetrozine then twice applications of pyriproxyfen and one application of diafenthiuron. (7 field applications).

The efficacy of the chemicals against nymphal stage treatments could be arranged in a descending order as follows.

$103>108>107>106>111>102>105>109>110>104>$ 101 .

The best result was given by treatment 103 as in the case of egg stage.

The efficacy of the chemicals used against immature stage (eggs+ nymphs), could be arranged in the following descending order.

$108>105>103>106>107>111>110>104>109>$ $102>101$.

The best result was given by 108 in which tomato seedlings treated at nursery with imidacloprid as drench application and at open field with imidacloprid as foliar application followed by twice applications of fenpropathrin, then twice applications of pymetrozine, then twice applications of pyriproxyfen then twice applications of diafenthiuron, then twice applications of lufenuron. (10 field applications) (Table3). This finding is in agreement with Castle et al., (2002) who stated that the rotation regimen generally performed better than the sequential treatments. Although his findings did not prove that insecticide rotation strategy was superior to the use of mixtures to control B. taboci.

Also, Palumbo et al., (1996) suggested that incorporation of imidacloprid into the upper $3-4 \mathrm{~cm}$ of 


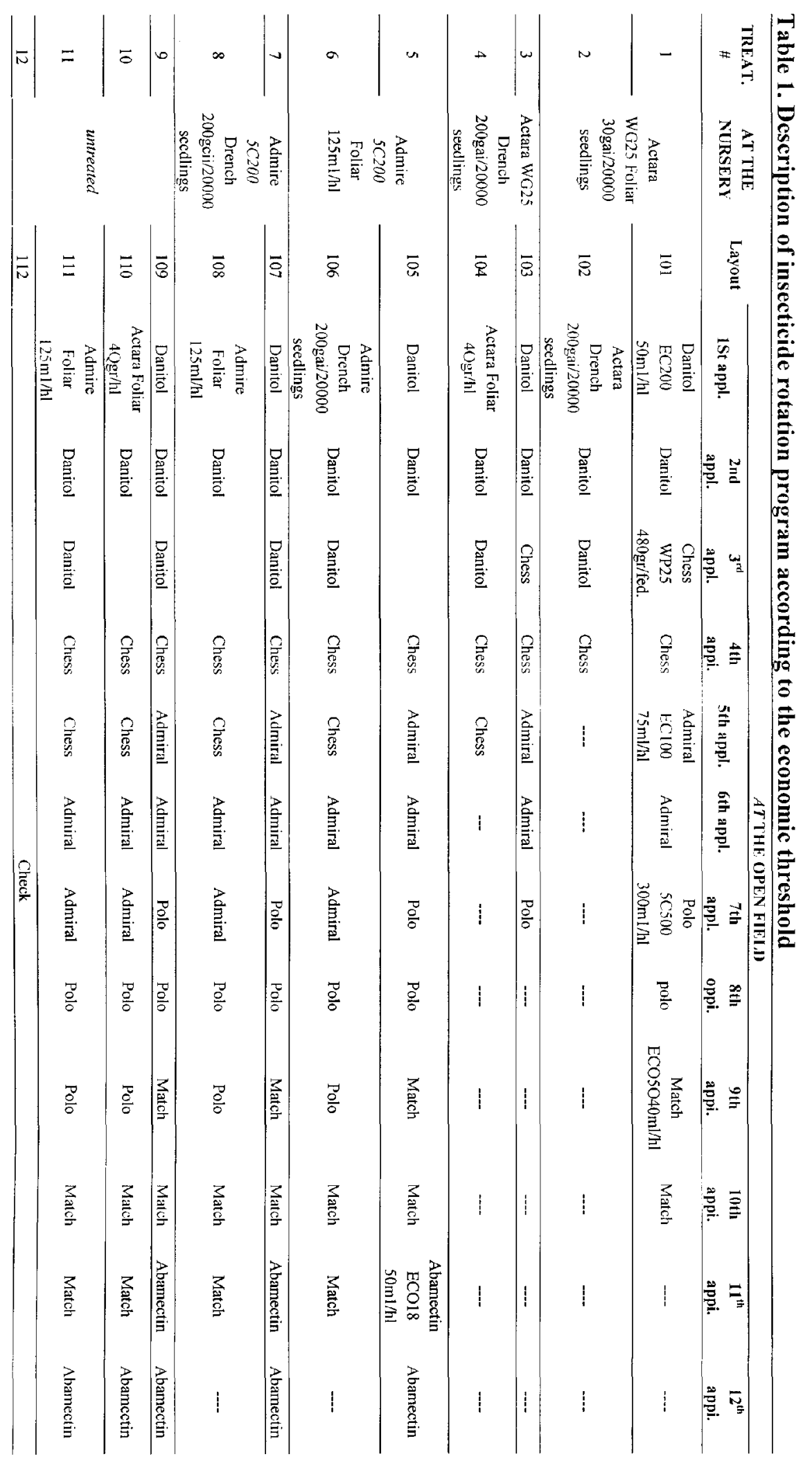




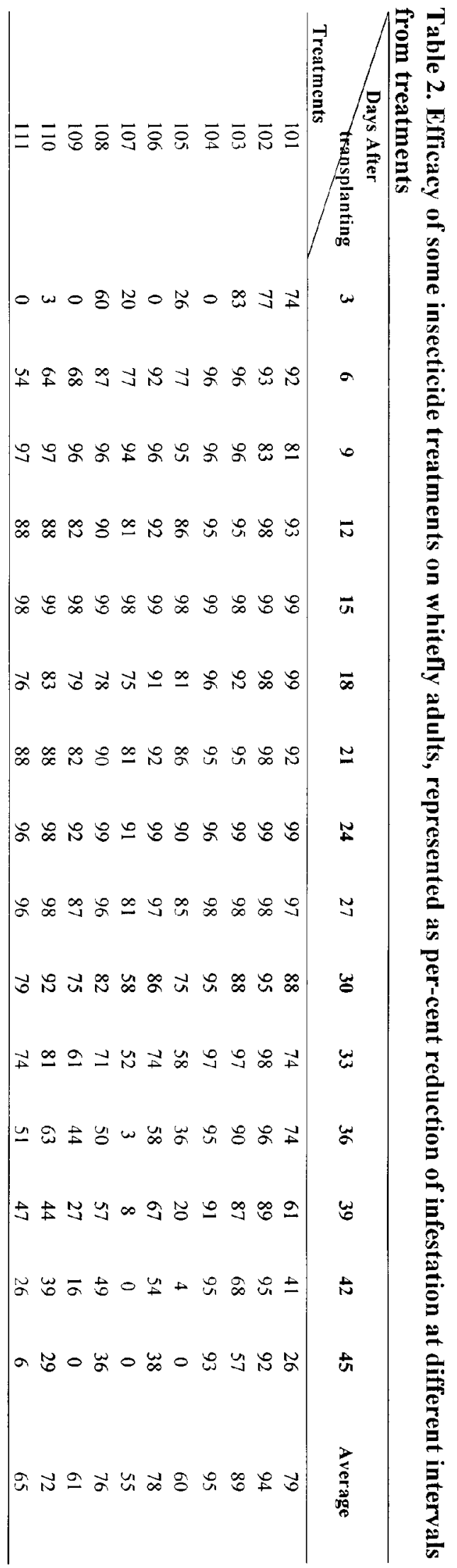




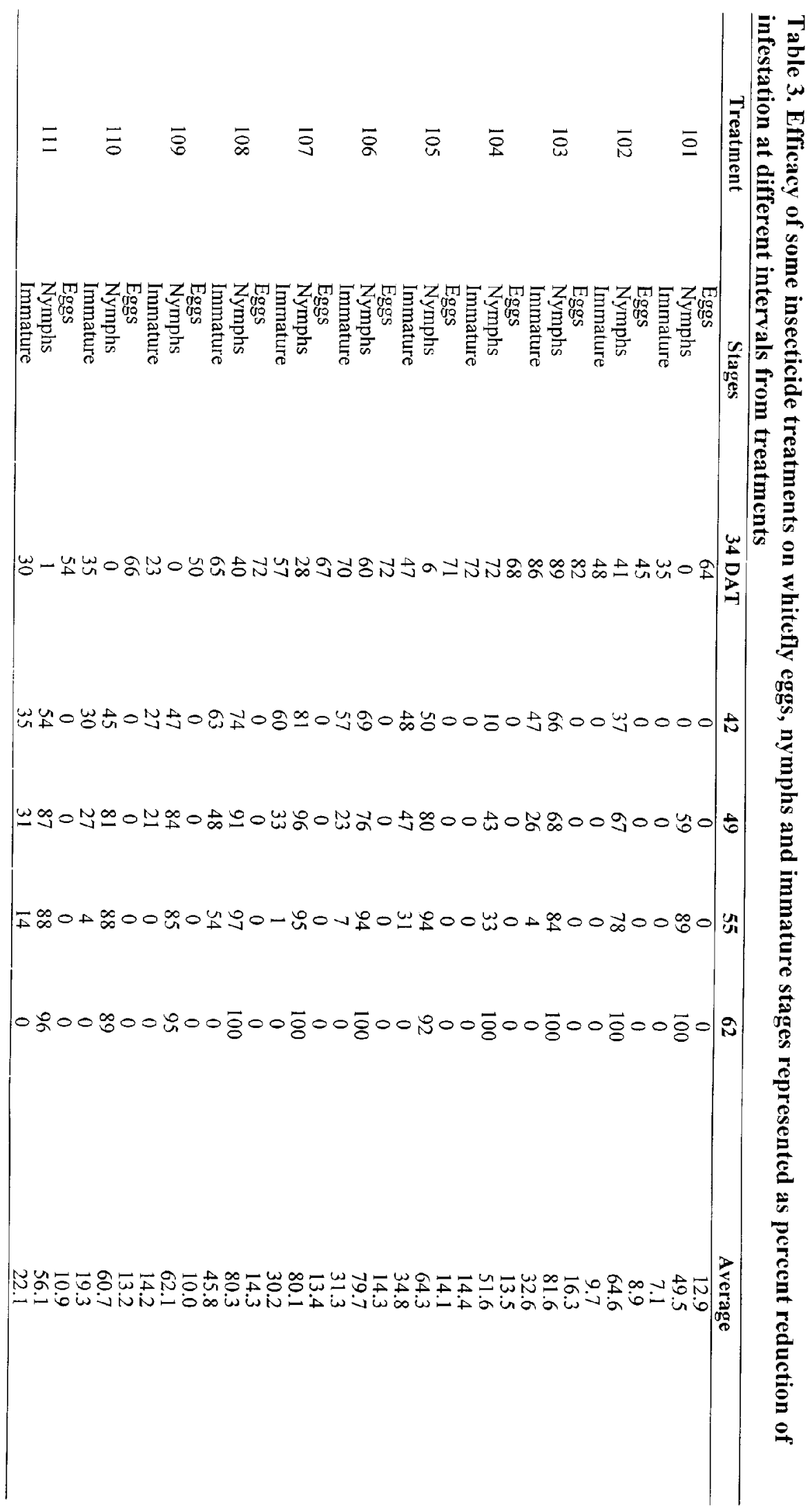




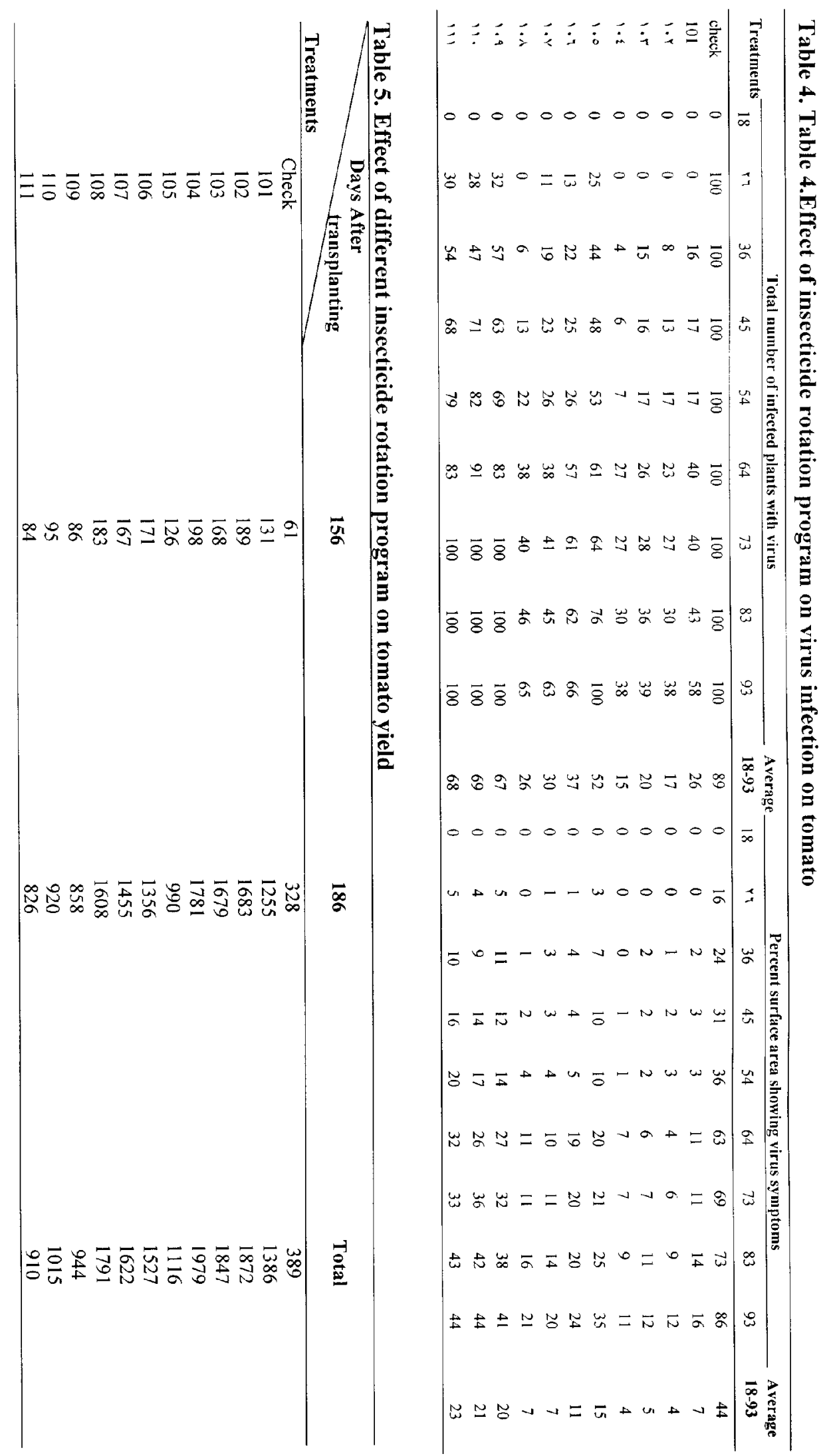


soil below the seed furrow is optimal for absorption and translocation. This treatment may provide a more environmentally suitable method measure tool and effective alternative to control $B$. taboci than is currently possible with foliar treatment. This finding supports our results which indicated that drench application is better than foliar one

The number of infected plants with virus and percent surface area showing virus symptoms was presented in Table 4.

Concerning the number of infected plants with virus, the best result was given by treatment 104 followed by 102,103=108,107 106,105, 109, 111, 110 and 112 , and the percent surface area showing virus symptoms in a descending order, the best result was given by treatment $102=104,103,101=107=108,106$, 105, 109, 110, and 111.

Treatment 104, 102 and 103 gave the best results for controlling adults, reducing the number of infected plants with virus and percent surface area showing virus symptoms and the highest yield of harvested tomatoes. Similarly Ayad et al., (2003) found that insecticide rotation gave good control of $B$. tabaci.

Also Ayad et al., (2002) found that seed treatment followed by insecticide rotation gave good control of $B$. tabaci as well as high yield showing the least the number of infected plants with minimal surface of virus symptoms.

From these results it could be suggested that drench application in the nursery followed by block application of insecticide in the field in a rotational program-insecticide reduced the number of application per season, delayed the development of resistance.

\section{REFERENCES}

Ayad, F. A.; Emara, M. M.; Rahal, M.M. and Bakry, N. M. (2002). Evaluation of tomato seed dressing in rotational spray program for the control of whitefly. $1^{\text {st }}$ Conf. of the Central Agric. Pesticde Lab. PP. 650 - 56.

Ayad, F. A.; Emara, M. M.; Rahal, M.M. and Ghallab, F. M.(2003). Evaluation of insecticidal rotation against cotton whitefly Bemisia tabaci on the Nili tomato crop. J. Pest. Cont \& Environ Sci. 11(2): 17 - 26.

Brown, J. K. (1992). Virus diseases of cotton. In ctton diseases, ed. RJ Hillocks pp. 276 330. Oxon. UK. Commonw. Agric. Bur. Int. 415 pp.

Butler, G. D; Jr. D. L. Coudriet and Hennebery (1988). Toxicity and repellence of soybeans and cotton seeds oils to the sweet potato whitefly and the aphids on cotton in greenhouse studies. Southwest. Entomol. 13 (2): 81 - 96.

Cahill, M.; Byrne, F.J.; Gorman, K.; Denholm, I. and Devonshire, A. L. (1995). Pyrethroid and organophosphate resistance in the tobacco whitefly,
Bemisia tabaci (Homoptera Aleyrodidae). Bull. Entomol. Res., 85: 181 - 187.

Cahill, M.; Denholm, I.; Day, S.; Elbert, A. and Nuen, R. (1996). Baseline determination and detection of resistance to imidacloprid in Bemisia tabaci (Homoptera: Aleyrodidae). Bull. Entomal. Res., 86: 343 - 349.

Costa, H. S. and Brown, J. K. (1991). Variation in biological characteristics and esterase pattern among populations of Bemisia tabaci, and the association of one population with silver leaf symptom induction. Entomol. Exp. Appl. 61: $211-219$.

Costa, H. S.; Brown, J. K and Byrne, D. N. (1991). Life history traits of the whitefly, Bemisia tabaci (Homoptera: Aleyrodidae). On six Virus infected or health plant species. Environ. Entomol. 20: 1102 - 1107.

Costa, H. S.; Brown, J. K.; Sivasupramnian, S. and Bird, J. (1993). Regional distribution, insecticide resistance, and reciprocal crosses between the A and B biotypes of Bemisia tabaci Insect. Sci. Appl. 14: 255 - 266.

Costa, S. J. Toscano, N. C.; Probhaer, N.; Henneberry, T. J. and Palumbo, J. C.(2002). Filed evaluation of different insecticide use strategies as resistance management and control tactics for Bemisia tabaci (Hemiptera: Aleyrodidae). Bull. Entomol. Res. 92(2): 449 - 460.

Curtis, C. E. (1985). Theoretical models of the use of insecticide mixtures for the management of resistance. Bull. Entomol. Res. $75: 259-265$.

Dittrich, V.; Ernst, G. H.; Rusech, O. and UK, S. (1990). Resistance mechanisms in Sweet potato whitefly (Homoptera: Aleyrodidae). populaton form Sudan, Turkey, Guatemala. and Nicaragua. J. Econ. Entomol. 83: $1665-1670$.

Dittrich, V.; Hasson, S. O. and Ernst, G. H. (1985). Sudanese cotton and the whitefly: a case study of the emergence of new primary pest. Crop Protection $4: 161-176$.

Georghiou, G. P. (1983). Management of resistance in arthropods pp. $769-792$ in Georghiou, G. P., Saito, T. (Eds) Pest Resistance to Pesticides. New York. Plenum.

Georghiou, G. P. (1994). Principles of insecticide resistance management. Phytoprotection 75 (suppl.): 51 - 59.

Henderson C. F. and Telton, E.W. (1955). Tests with acoricides against the brown wheat mite. J. Econ. Entomol., 48: 157 - 161.

Horowitz, A. R., Toscano, N.C., Youngman, R. R. and Georghiou, G. P. (1988). Synergism of insecticides with DEF in sweetpotato whitefly (Homoptera: Aleyrodidae). J. Econ. Entomol., 81: 110 - 114.

Immaraju, J.A. Morse, J. G and Hobza, R. E. (1990). Field evaluation of insecticide rotation and mixtures as strategies for citrus thrips Thysanoptera: Thripidae) resistance management in California. J. Econ. Entomol. 83: $306-314$.

Keiding, J. (1986). Prediction or resistance risk assessment. pp. $279-297$ in National Research Council (Eds) 
Pesticide Resistance Strategies and Tactics for Management. Washington, Dc, Nationl Academy Press.

Mkkenzie, C. L. and Byford, F. L. (1993) Continuous alternating and mixed insecticides affect development of resistance in the house fly (Diptera: Muscidae). J. Econ. Enomal., 86: 1040 - 1048.

Palumbo, J. C; Kerns, D. L; Engle, C. E; Sanchez, C. A. and Wilcox, M. (1996). Imidacloprid formulation and soil placement effects on colonization by sweet potato whitefly (Homoptera: Aleyrodidae): Head size and incidence of chlorosis in lettuce. J. Econ. Entomol., 89(3): $735-742$.
Prabhaker, N.;Coudriet, D. L. and Meyerdirk, D. L. (1985) Insecticide resistance in the sweet potato whitefly, Bemisia tabaci (Homoptera: Aleyrodidae). J. Econ. Entomol., 78: 748 - 752.

Prabhaker, N.; Toscano, N.C., Perring, T. M.; Nuessly, G.,K: do, K. and Youngman, R. R. (1992). Resistance monitoring of the sweet potato whitefly (Homoptera: Aleyrodidae). In the Imperial Valley of California J. Econ0 Entomol., 85: 1063 - 1068.

Tabashnik, B. E. (1989). Managing resistance with multiple pesticide tactics theory, evidence and recommendations. J. Econ. Entomol., 82: 1263 - 1269. 


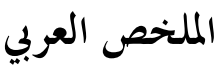

\section{برامج دوريه لترشيد استخدام المبيدات لمكافحه الذبابة البيضاء علي الطماطم}

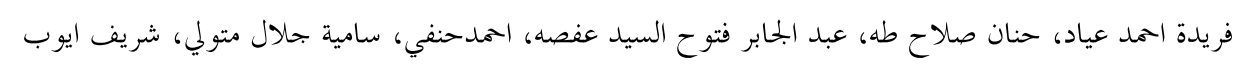

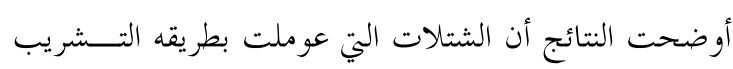

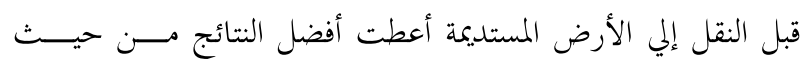

تم تقييم اثني عشر معامله بالمبيدات التقليدية وغير التقليدية في

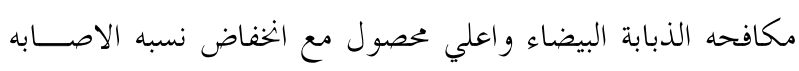

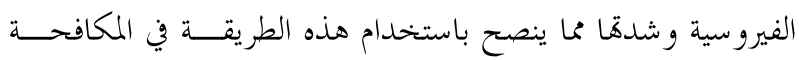

مرامج دوريه علي صنف طماطم Rover (E-446) F1 hybrid

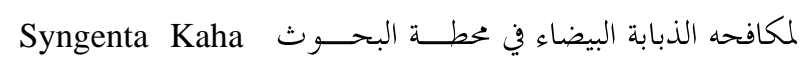

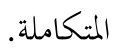

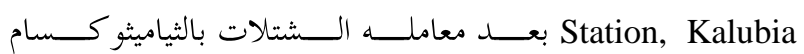

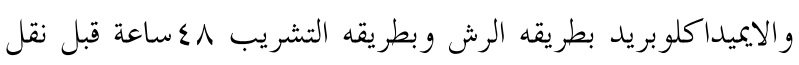

الشتلات إلي الأرض المستديمة. 
